\title{
Water Disinfection \\ A Practical Approach to Calculating Dose Values for Preharvest and Postharvest Applications
}

\author{
Trevor V. Suslow, Postharvest Specialist, University of California, Davis, \\ Department of Vegetable Crops, Mann Lab
}

\section{WHY WATER DISINFECTION IS NEEDED}

Clean, disinfected water is necessary to minimize the potential transmission of pathogens from water to produce, from healthy to infected produce within a lot, and from one lot to another over time. Waterborne microorganisms, including postharvest plant pathogens and agents of human illness, can be rapidly acquired and taken up on plant surfaces. Natural plant surface contours, natural openings, harvest and trimming wounds, and scuffing can be points of entry as well as safe harbor for microbes. In these protected sites, microbes are largely unaffected by common or permitted doses of postharvest water treatments, such as chlorine, chlorine dioxide, ozone, peroxide, and peroxyacetic acid. Therefore, it is essential that enough sanitizer is maintained in water to kill microbes before they attach or become internalized in produce. This is important in some preharvest water uses and in all postharvest procedures involving water, including washing, cooling, water-mediated transport (flumes), and postharvest drenching.

\section{MINIMUM EFFECTIVE DOSES}

Standards for the microbial quality of water should increase closer to harvest maturity and as produce moves from the field to final processing. However, excessive treatment, particularly hyperchlorination (use of high levels of chlorine), has several known and potential negative effects on product sensory quality, the environment, and human health. Water treatment should be managed with the goal of minimizing the effective dose of sanitizer used for microbial disinfection. Minimum effective doses are typically represented as the product of Concentration (C) and Time of exposure $(t)$, or $C t$. Following the same principles, the term disinfection hurdle $\left(D_{h}\right)$ can be used to help guide water quality management. The disinfection hurdle is the minimum point at which there is enough free active disinfectant available to neutralize microbial activity to an acceptable level.

\section{CHLORINE AND HYPOCHLORITE (BLEACH) TREATMENT}

Ease of use and relative low cost make hypochlorite (usually liquid sodium hypochlorite) a very common water disinfectant in the produce industry. The antimicrobial activity of chlorine compounds depends largely on the amount of hypochlorous acid ( $\mathrm{HOCl}$ ) present in the water after the treatment is applied. This, in turn, depends on the $\mathrm{pH}$ of the water, the amount of organic material in the water, and, to a more limited extent, the temperature of the water. Above $\mathrm{pH} 7.5$, very little $(<50 \%)$ chlorine can exist as active $\mathrm{HOCl}$ while most becomes inactive hypochlorite $\left(\mathrm{OCl}^{-}\right)$. With very long contact time, $\mathrm{OCl}^{-}$does have some antimicrobial activity but would not be expected to result in beneficial control in typical postharvest handling systems. Below $\mathrm{pH}$ 6.0, noxious chlorine gas $\left(\mathrm{Cl}_{2}\right)$ is formed and does not serve as an effective water disinfectant. Of the many possible forms of chlorine, $\mathrm{HOCl}$ is the most readily transferred across a microbial cell wall to begin the killing process. Thus, in the management of chlorine, it is important to maximize $\mathrm{HOCl}$ concentrations and minimize all other forms of chlorine. It is highly desirable to keep the $\mathrm{pH}$ of the water between 6.0 and 7.5 to ensure adequate $\mathrm{HOCl}$ activity without the formation of chlorine gas, which can lead to health problems for workers and more corrosion on equipment.

The amount of $\mathrm{HOCl}$ needed to maintain the most active antimicrobial action depends on several dynamic factors. Chlorine is very reactive, combining with almost any oxidizable material to form secondary compounds. The amount of chlorine needed for disinfection of water depends not only on the $\mathrm{pH}$ but also on the amounts and kinds of inorganic (particularly ammonia, nitrites, iron, and manganese) and organic (particularly amino acids and simple proteins) substances present in the water. Because chlorine is rapidly used up by organic and inorganic molecules in wash water, a minimum level of total chlorine, the chlorine demand, (generally influenced by soil, plant "trash," and exudates from cut surfaces) must first be satisfied in the water 
before sufficient amounts of free available chlorine can kill microorganisms. The treatment times of fruits and vegetables are usually very short. To minimize the potential for excessive chlorination at peak chlorine demand, it is important to periodically replace or filter the water and blend it with potable water.

\section{CALCULATING REQUIRED HOCI ADDITIONS}

In clean water, very low levels of $\mathrm{HOCl}$ kill most bacteria and some viruses. Approximately 1 minute with 1 to 2 parts per million $\mathrm{HOCl}$ should be sufficient contact time. As water quality decreases and complexity increases, contact time or concentration must increase to maintain adequate microbial kill. Because contact times during postharvest handling are usually determined by product flow requirements, it is the concentration of the added disinfectant that is adjusted. Effective concentrations of $\mathrm{HOCl}$ (or other forms of chlorine) should ideally be determined by microbial testing within each system. Water quality management is often perceived as a time-consuming and costly activity; however, it is strongly recommended that it receive a high level of attention.

As a starting point, the calculations below can be made to determine the minimum concentration of free available chlorine as $\mathrm{HOCl}$ in wash or cooling water that is needed to kill free-floating pathogenic bacteria and viruses. The calculations are based on an adaptation of tables that were developed to achieve potable water quality standards in treated water. Higher levels of $\mathrm{HOCl}$ or other treatments are needed for Bacillus or Clostridium spores and for parasites like Giardia and Cryptosporidium.

Use table 1 to calculate the target measured concentration of $\mathrm{HOCl}$ and match it with the contact time of the system to establish the effective dose.

\section{Example}

Based on the contact time of the system, calculate the $\mathrm{HOCl}$ concentration necessary for an effective dose. For washing and cooling, the system has a 5-minute residence time $(t)$, and the water has a $\mathrm{pH}$ that is constant around 7.5 to 7.8 without adjustment when product is running through the system. The water temperature is maintained at $34^{\circ}$ to $38^{\circ} \mathrm{F}\left(1.1^{\circ}\right.$ to $\left.3.3^{\circ} \mathrm{C}\right)$. The table shows that the disinfection hurdle, $D_{h}$, is 20 . Using these known values in the following equation, solve for $C$, the minimum $\mathrm{HOCl}$ concentration.

$$
C=D h \div t \text { or } 20 \div 5=4 \mathrm{mg} / \mathrm{L}(4 \mathrm{ppm})
$$

Using this result, free available chlorine can be measured using a titration kit or colorimeter specific for free available chlorine. At $\mathrm{pH} 7.8$ and $34^{\circ}$ to $38^{\circ} \mathrm{F}\left(1.1^{\circ}\right.$ to $3.3^{\circ} \mathrm{C}$ ), only 50 percent of the measured free available chlorine, by the commonly used methods, is in the desired $\mathrm{HOCl}$ form. Therefore, a minimum reading of 8 parts per million is needed to hit the targeted disinfection hurdle.

Remember, the calculated amount may be very
different from the actual dose of total hypochlo-
rite solution added to the system at peak
demand. The target $D_{h}$ is determined by the sen-
sitivity of the most resistant microbe being man-
aged. (Erwinia soft rot bacteria and E. coli are rela-
tively sensitive, Geotrichum sour rot and
Rhizopus are much more resistant.) Microbe sensi-
tivity must be determined by direct testing
because sensitivity charts calibrated to this sys-
tem of calculating effective doses are not yet
available.

It is easy to see the impact of water $\mathrm{pH}$ on $\mathrm{C}$. In the same example, adding citric acid to maintain $\mathrm{pH} 7.0$, $C=2.75$ parts per million $(\mathrm{HOCl}$ is $87 \%$ of free chlorine at $\mathrm{pH}$ 7.0). It is common for $\mathrm{pH}$ to increase to 8.5 during hypochlorite treatment, resulting in $C=41$ parts per million $(\mathrm{HOCl}$ is $17.5 \%$ of free chlorine at $\mathrm{pH} 8.5)$.

It is important to remember that test kits for measuring free available chlorine are only suitable for concentrations of up to 4 parts per million. It is necessary to dilute any treated water with distilled water to bring it into a measurable range and then to multiply the result by the dilution factor. Typical dilutions are 1:10 although a dilution of 1:100 may be necessary where concentrations of disinfectant are high due to the increased importance of controlling fungal spores. Always follow the instructions provided by the test kit supplier.

It is easiest to adjust and standardize water $\mathrm{pH}$ to 6.5 to 7.0 , causing the majority of free available chlorine to convert to the $\mathrm{HOCl}$ form. Consulting a second table of $\mathrm{pH}$ and temperature then becomes unnecessary. Measurements of $\mathrm{HOCl}$ in water may also be adequately determined by using a calibrated ORP (oxidation reduction potential) sensor. As in the first example, 4 to 6 parts per million $\mathrm{HOCl}$ typically gives a sensor reading of 725 to 750 millivolts. 
Table 1. Guidelines for meeting the disinfection hurdle in postharvest water treatment*

\begin{tabular}{l|c|c}
\hline & \multicolumn{2}{c}{ Value of $D_{h}$ in $C \times \mathbf{t}=\boldsymbol{D}_{h}$} \\
\cline { 2 - 3 } Water $\mathbf{p H}$ range & $\mathbf{3 2 ^ { \circ }}$ to $^{\mathbf{4}} \mathbf{1}^{\circ} \mathbf{F}$ & $\mathbf{5 0 ^ { \circ }} \mathbf{F}$ \\
\hline $7.0-7.5$ & 12 & 8 \\
$7.5-8.0$ & 20 & 15 \\
$8.0-8.5$ & 30 & 20 \\
$8.5-9.0$ & 35 & 22 \\
\hline
\end{tabular}

*Values given are the product of concentration of $\mathrm{HOCl}$ and time of exposure of a diversity of microbes in water to achieve greater than 99 percent kill. The value $t$ is determined by the specific process or operation and assumes adequate mixing to accomplish uniform exposure.

Source: Modified from White 1992 and reflect results from laboratory and field research data.

Table 2. Current projected value of $D_{h}$ in postharvest water at $\mathrm{pH} 7.0$

\begin{tabular}{l|c|c}
\hline $\begin{array}{l}\text { Target } \\
\text { microorganism }\end{array}$ & $\mathbf{3 2}^{\circ}$ to $\mathbf{4 \mathbf { 1 } ^ { \circ } \mathbf { F }}$ & $\begin{array}{c}\text { Typical contact } \\
\text { time (minutes) }\end{array}$ \\
\hline $\begin{array}{l}\text { Non-spore-forming } \\
\text { bacteria }\end{array}$ & $3-6$ & $1-5$ \\
\hline Many viruses & $3-10$ & $1-5$ \\
\hline Many yeasts & $75-100$ & $10-30$ \\
\hline $\begin{array}{l}\text { Spore-forming } \\
\text { bacteria }\end{array}$ & $150-250$ & $15-60$ \\
\hline Fungal spores & $150-500$ & $15-60$ \\
\hline $\begin{array}{l}\text { Parasite spores } \\
\text { Giardia } \\
\text { Cryptosporidium }\end{array}$ & $\begin{array}{c}30-100 \\
\text { highly tolerant }\end{array}$ & $\begin{array}{c}5-10 \\
\text { use UV or ozone }\end{array}$ \\
\hline
\end{tabular}

Source: Modified from White 1992 and reflect results from laboratory and field research data.

\section{GLOSSARY OF TECHNICAL TERMS}

Antimicrobial activity. The effectiveness of a sanitizer or disinfectant in killing microorganisms.

Corrosive. The capacity of an element to weaken or eat away at equipment, especially metal.

Disinfection. The act of adding or applying a sanitizer to kill microorganisms that cause decay in produce or illness in humans.

Disinfection hurdle. A descriptive concept term that symbolizes the minimum effective exposure to achieve microbial kill. Disinfection is one of several hurdles in a prevention, reduction, and contamination control pro- gram. The disinfection hurdle is different for different types and classes of microorganisms.

Pathogens. Microorganisms such as bacteria, fungi, parasites, and viruses that can cause disease in humans or plants.

Peak chlorine demand. The maximum amount of chlorine in a batch of water that is occupied, or "used up," by inorganic and organic material. After the peak chlorine demand is known, it can be better established how much more chlorine or more clean water should be added to maintain the target disinfection hurdle. Additional steps, such as minimizing adhering soil, prewashing, or filtration may be necessary to reduce the peak chlorine demand.

Potable water. Water that is clean enough to be considered drinkable.

Product sensory. Characteristics of a product, in this case fresh produce, related to smell, taste, appearance, and texture.

Reactive. A chemical that is especially reactive is one that does not stay in one form for very long. In the case of water disinfection, it is important that chlorine stay in a particular form $(\mathrm{HOCl})$ in order to be effective, making the reactivity of chlorine of particular interest.

Sanitizer. A chemical that is added or applied, in this case to water, in order to kill pathogens. A surface or water can be sanitized and free of pathogens, but sanitizing does not make the material or the water sterile.

Sensitivity. The sensitivity of a system or test refers to the lowest concentration that the system or test can detect or respond to. For example, if a chlorine test can only detect concentrations of chlorine at or higher than $1 \mathrm{ppm}$, the system's sensitivity is said to be at $1 \mathrm{ppm}$.

\section{ADDITIONAL INFORMATION}

Below are some of the many articles, research papers, and reviews available about this broad topic.

Suslow, T. 1997. Postharvest chlorination: Basic properties and key points for effective sanitation. Oakland: University of California Division of Agriculture and Natural Resources, Publication 8003. http:/ / anrcatalog.ucdavis.edu

Suslow, T. 1998. Introduction to ORP as the standard of postharvest water disinfection monitoring. http:/ / vric.ucdavis.edu (Go to Vegetable Information and click on Topics: Food Safety.)

Suslow, T. 1998. Prevention of postharvest water infiltration into fresh market tomatoes: Food safety and spoilage control practices. http:/ / vric.ucdavis.edu (Go to Vegetable Information and click on Topics: Food Safety.)

White, G. C. 1992. Handbook of chlorination and alternative disinfectants. $3 \mathrm{~d}$ ed. New York: Van Nostrand Reinhold. 
You'll also find detailed information on many aspects of postharvest technology in these titles and in other publications, slide sets, and videos from UC ANR:

Postharvest Biology of Horticultural Crops: An Overview, slide set $84 / 117$

Postharvest Chlorination: Basic Properties and Key Points for Effective Distribution, publication 8003

Postharvest Technology of Horticultural Crops, 2d edition, publication 3311

\section{ORDERING}

To order these products, visit our online catalog at http:/ / anrcatalog.ucdavis.edu. You can also place orders by mail, phone, or fax, or request a printed catalog of publications, slide sets, and videos from

University of California

Agriculture and Natural Resources

Communication Services

6701 San Pablo Avenue, 2nd Floor

Oakland, California 94608-1239

Telephone: 800-994-8849 or 510-642-2431

FAX: 510-643-5470

E-mail inquiries: danrcs@ucdavis.edu

Visit the ANR Communication Services website at http://anrcatalog.ucdavis.edu.

Publication 7256

(C) 2001 by the Regents of the University of California, Division of Agriculture and Natural Resources. All rights reserved.

The University of California prohibits discrimination against or harassment of any person employed by or seeking employment with the University on the basis of race, color, national origin, religion, sex, physical or mental disability, medical condition (cancer-related or genetic characteristics), ancestry, marital status, age, sexual orientation, citizenship, or status as a covered veteran (special disabled veteran, Vietnam-era veteran or any other veteran who served on active duty during a war or in a campaign or expedition for which a campaign badge has been authorized).

University Policy is intended to be consistent with the provisions of applicable State and Federal laws. Inquiries regarding the University's nondiscrimination policies may be directed to the Affirmative Action/Staff Personnel Services Director, University of California, Agriculture and Natural Resources, 300 Lakeside Drive, 6thFloor, Oakland, CA 94612-3550; 510-987-0096. For information on how to obtain this publication and other ANR CS products, call 800-994-8849.

pr-9/01-GM/GM

ISBN 978-1-60107-047-0

This publication has been anonymously peer reviewed for technical accuracy by University of California scientists and other qualified professionals. This review process was managed by the ANR Associate Editor for Vegetable Crops. 